\title{
Atrioventricular septal defect - anatomic characteristics in patients with and without Down's syndrome
}

\author{
Bruno Marino
}

T he recent issue of Cardiology in the Young (October 1991, Volume 1, Number 4) was concerned exclusively with papers on atrioventricular septal defects. These papers were interesting and accurate. Little attention was paid, nonetheless, by the various authors to the anatomic differences between patients with and without Down's syndrome, and, obviously, no consideration was given to possible implications for clinical and surgical aspects of the lesion. The presence of Down's syndrome cannot be considered occasional in patients with an atrioventricular septal defect since it occurs in one-third to one-half of cases, according to different published series. ${ }^{1-3}$ One of the differences between patients with and without Down's syndrome is the higher prevalence of forms with common, as opposed to separate, valvar orifices in the presence of trisomy 21 and, vice versa, of the forms with separate right and left valvar orifices in patients with normal chromosomes. ${ }^{2-4}$ Furthermore, when the variant with a common atrioventricular orifice is present in patients without Down's syndrome, Rastelli type $\mathrm{A}^{5}$ and the so-called intermediate form, prevail. ${ }^{6}$

Another interesting finding is that, in patients with an atrioventricular septal defect without Down's syndrome, the left (or "mitral") valve tends to be attached to the crest of the ventricular septum, and this can be the substrate for obstruction of the left ventricular outflow tract. ${ }^{7,8}$

In 1986, we provided the first statistical documentation of the prevalence of obstructions of the left ventricular outflow tract in patients with atrioventricular septal defect without Down's syndrome," including both patients with a common atrioventricular orifices and also those with separate right and left valvar orifices. We also cited previous anatomic studies ${ }^{1-10}$ that supported these data. Thus, in 1978, Freedom, Bini and Rowe ${ }^{10}$ reported 12 patients with significant hypoplasia of the left ventricle of whom only one $(8.3 \%)$ had Down's syndrome. In 1984, Van Praagh and colleagues $^{1}$ described 12 patients with stenosis of the subaortic outflow tract of whom three $(25 \%)$ had Down's syndrome. Penkoske and colleagues ${ }^{2}$ reported only six specimens (15\%) with left-sided anomalies among 39 cases with Down's syndrome, while leftsided anomalies were found in 28 out of $56(50 \%)$ hearts from patients without Down's syndrome. In a more recent report, de Leon and colleagues ${ }^{11}$ described the surgical treatment of 12 patients with subaortic stenosis. Only three of them had Down's syndrome. Interestingly, the subaortic obstruction was recognized before repair of the atrioventricular septal defect in only two cases. One could speculate that increasing awareness of this potential problem in patients without Down's syndrome might allow for an earlier diagnosis, thus avoiding the need of reoperation in such patients.

In contrast, data reported by Gow and colleagues ${ }^{12}$ seem to diverge from these concepts. In 30 patients with an atrioventricular septal defect and either aortic coarctation or subaortic stenosis, they did not find significant differences between patients with (13 cases) and without (17 cases) Down's syndrome. In their selection of patients, however, the authors excluded two cases with bicuspid aortic valve: one patient with severe aortic stenosis and all patients with right ventricular dominance. Our studies $3,9,13-16$ in patients with atrioventricular septal defect have suggested that the main difference between patients with and without Down's syndrome is probably related to the morphology of the left ventricular inlet. Thus, malalignment or malorientation of the atrioventricular junctions (right ventricular dominance or double outlet right atrium), and malformations of the left atrioventricular valve (double orifice) and of its subvalvar apparatus (parachute valve), occur more often in patients without Down's syndrome. These associated anomalies may cause various degrees of hypoplasia of the left ventricle $3,9,10,13,15,16$ and also affect the development of the left ventricular outflow tract and/or the aortic arch.

This increased prevalence of right ventricular dominance, and the association with left-sided obstructions 
in the subgroup of patients with usual atrial arrangement, atrioventricular septal defect, and normal chromosomes are similar to those observed in patients with isomerism of the left atrial appendages and the polyspenia syndrome. ${ }^{17}$

Another recently recognized feature ${ }^{18,19}$ is the rarity of additional ventricular septal defects in the apical muscular septum of patients with atrioventricular septal defect and Down's syndrome. This new information was recently endorsed by the investigators of the Baltimore-Washington Infant Study who had previously confirmed the rarity of left-sided anomalies in patients with Down's syndrome. ${ }^{20}$ While the causes of this anatomical differences are unknown, their important clinical and surgical implications should be recognized. Patients with a degree of left-sided obstruction, the most severe being stenosis of the inlet, may present early in life with profound congestive heart failure., $, 10,13,15$ The surgical options vary according to the type and severity of the associated malformations. Recent studies describe a higher surgical mortality in parients without Down's syndrome after repair of cases with both separate $^{15}$ and common ${ }^{22-24}$ atrioventricular orifices. It is also the case that infants without Down's syndrome carry a significantly higher hazard of need for reoperation to correct severe post-operative regurgitation of the left atrioventricular valve compared to those with trisomy $21 . .^{25-27}$

In conclusion, therefore, patients with atrioventricular septal defect without Down's syndrome differ from those with trisomy 21 because of the higher risk of leftsided anomalies. This notion must be considered in the light of anatomical studies, in the diagnostic assessment, and in the surgical treatment of these parients. Furthermore, these children with normal chromosomes may also have serious extracardiac anomalies representing, in a number of cases, recognizable syndromes. ${ }^{23,28,29}$

The increasing interest for the genetic imprinting in congenital heart diseases may now stimulate further studies on morphogenesis and anatomy of atrioventricular septal defect to the better understanding of clinical and surgical findings of all categories of patients with this malformation.

\section{Department of Pediatric Cardiology \\ Bambino Gesù Hospital \\ Via San Onofrio 4 \\ Rome, Italy}

\section{References}

1. Van Praagh S, Antoniadis S, Otero-Coto E, Leidenfrost RD, Van Praagh R. Common atrioventricular canal with and without conotruncal malformations: an anatomic study of
251 postmortem cases. In: Congenital Heart Disease: Causes and Processes. Nora JJ, Takao A (eds). Futura Publishing Co, Mount Kisco, New York, 1984, pp 599-639.

2. Penkoske PA, Neches WH, Anderson RH, Zuberbuhler JR. Further observations on the morphology of atrioventricular septal defects. J Thorac Cardiovasc Surg 1985; 90: 611-622.

3. Marino B, Vairo U, Corno A, Nava S, Guccione P, Calabro R, Marcelletti C. Atrioventricular canal in Down syndrome. Prevalence of associated cardiac malformations compared with patients without Down syndrome. Am J Dis Child 1990; 144: 1120-1122.

4. Bharati S, Lev M. The spectrum of common atrioventricular orifice (canal). Am Heart J 1973; 86: 553-561.

5. Rastelli GC, Kirklin JW, Titus JL. Anatomic observations on complete form of persistent common atrioventricular canal with special reference to atrioventricular valves. Mayo Clin Proc 1966; 41: 296-308.

6. Marino B. Unpublished data

7. Wright JS, Newman DC. Complete and intermediate atrioventricular canal in infants less than a year old: observations of anatomical and parhological variants in left ventricular outflow tract. Ann Thorac Surg 1982; 33: 171-173.

8. Piccoli GP, Wilkinson JL, Macartney FJ, Gerlis LM, Anderson RH. Left-sided obstructive lesions in atrioventricular septal defects. An anatomic study. J Thorac Cardiovasc Surg 1982; 83: 453-460.

9. De Biase L, Di Ciommo V, Ballerini L, Bevilacqua $M$, Marcelletti C, Marino B. Prevalence of left-sided obstructive lesions in patients with atrioventricular canal without Down syndrome. J Thorac Cardiovasc Surg 1986; 91:467-469.

10. Freedom RM, Bini M, Rowe RD. Endocardial cushion defect and significant hypoplasia of the left ventricle: a distinct clinical and parhological entity. Eur J Cardiol 1978; 7: 263 281.

11. DeLeon SY, Ilbawi MN, Wilson WR, Arcilla RA, Thilenius OG, Bharati S, Lev M, Idriss F. Surgical options in subaortic stenosis associated with endocardiac cushion defects. Ann Thorac Surg 1991; 52: 1076-1083.

12. Gow RM, Freedom RM, Williams WG, Trusler GA, Rowe RD. Coarctation of the aorta or subaortic stenosis with atrioventricular septal defect. Am J Cardiol 1984; 53: 1421-1426.

13. Corno A, Marino B, Catena G, Marcelletti C. Atrioventricular septal defects with severe left ventricular hypoplasia. J Thorac Cardiovasc Surg 1988; 96: 249-252.

14. Marino B. Anterolateral muscle bundle of the left ventricle in atrioventricular septal defect: left ventricular outflow tract and subaortic stenosis. Pediatr Cardiol 1992. [In press]

15. Giamberti A, Marino B, Di Donato R, Grazioli S, Marcelletti C. Canale atrioventricolare parziale: fattori di deterioramento clinico e risultati chirurgici nel primo anno di vita. G Ital Cardiol 1990; 20: 19.

16. Troconis CJ, Di Donato RM, Marino B, Vairo U, Marcelletti C. Atrioventricular septal defects with severe left ventricular hypoplasia. Clinical findings and surgical options. Cardiol Young 1992; 2: 53-55.

17. Peoples WM, Moller JH, Edwards JE. Polysplenia: a review of 146 cases. Pediatr Cardiol 1983; 4: 129-138.

18. Papa M, Marino B, Vairo U, Nava S, Parretti Di Iulio D, Donfrancesco C, Cicini MP, Grazioli S, Mazzera E, Marcelletti C. Difetto interventricolare muscolare nel canale atrioventricolare. G Ital Cardiol 1990; 20: 801-804.

19. Marino B, Corno A, Guccione P, Marcelletti C. Ventricular septal defect and Down's syndrome. Lancet 1991; 2: 245-246.

20. Brenner JI. Personal communication, November 1991. 
21. Ferencz C, Neill CA, Boughman JA, Rubin JD, Brenner JI, Perry LW. Congenital cardiovascular malformations associated with chromosome abnormalities: an epidemiologic study. J Pediatr 1989; 114: 79-86.

22. Schneider DS, Zahka KG, Clark EB, Neill CA. Parterns of cardiac care in infants with Down syndrome. Am J Dis Child 1989; 143: 363-365.

23. Vet TW, Ottenkamp J. Correction of atrioventricular septal defect. Results influenced by Down syndrome. Am J Dis Child 1989; 143: 1361-1365.

24. Marino B, Marcelletti C. Unpublished data

25. Marino B. Valve insufficiency after atrioventricular septal defect repair: differences between patients with and without Down's syndrome. Ann Thorac Surg 1990; 50: 854-860.

26. Abbruzzese PA, Napolenoe A, Bini RM, Annecchino FP, Merlo M, Parenzan L. Valve insufficiency after atrioventricu- lar septal defect repair: differences between patients with and without Down's syndrome. Ann Thorac Surg 1990; 50: 854860

27. Weintraub RG, Brawn WJ, Venables AW, Mee RBB. Twopatch repair of complete atrioventricular septal defect in the first year of life. Results and sequential assessment of atrioventricular valve function. J Thorac Cardiovasc Surg 1990; 99 320-326.

28. Marino B, Guccione P, Corno A, Papa M, Marcelletti C, Dallapiccola B. Facial anomalies in patients with atrioventricular canal and normal chromosomes: the non-Down atrioventricular canal syndrome. Eur Heart J 1989; 10: 285-288.

29. Marino B, Guccione P, Marcelletti C, Dallapiccola B. Atrioventricular canal without Down syndrome associated with additional cardiac and noncardiac anomalies. Am J Dis Child 1990; 144: 752-756.

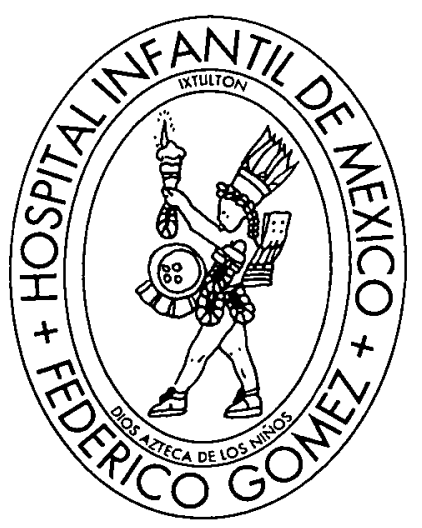

50th Anniversary Celebration of the founding of Hospital Infantil de México "Federico Gómez"

International Symposium-Atrioventricular Septal Defects FROM MOLECULAR BIOLOGY TO SURGICAL REPAIR

México City 26-27 April 1993

Organized by Dra. Maria Victoria de la Cruz

INVITED FACULTY

R. Markwald

J. M. Doménech Mateu

USA

R. H. Anderson England

R. Freedom Canada

B. Soto USA

F. Puga USA

Correspondence to Dra. Maria Victoria de la Cruz Hospital Infantil de México "Federico Gómez"

Dr. Márquez 162, Col. Doctores Deleg. Cuauhtémoc, 06720, México, D.F.

Fax. 91-5-761-0270

Stouffer President Hotels and Resorts Tel. 91-5-327-7700; Fax. 91-5-327-7787 